\title{
Application of Cogeneration on a Housing Complex
}

\author{
M. Atmaca, E. Yilmaz, and A. B. Kurtulus
}

\begin{abstract}
Cogeneration systems and equipment suitable for residential and small-scale commercial applications like hospital, hotel or institutional building are available, and new systems have developed. These products are used or aimed for meeting the electrical and thermal demands of a building for space and domestic hot water heating. In last years cogeneration has played a significant role in Turkish energy strategy, with plans to satisfy the considerable portion of Turkey's requirements for electricity from cogeneration. The main purpose of this work is to supply the demand for electricity and heat for housing complex in Turkey.

In this study, it is showed that cogeneration systems in housing complex are an extremely profitable investment for country and consumers. Here application of cogeneration on housing complex was made in Istanbul. It is stressed that this technology should be applied as an energy method in old and new housing complex.

The aim of this paper is to maintain a study by using real consumptions of housing complex in Turkey. Electricity and natural gas consumption quantities have been obtained from housing complex. Finally as it is resulted from payback period approach the system is paid off itself in 1.33 year, approximately 16 months.
\end{abstract}

Index Terms-Cogeneration, energy efficiency, Turkey.

\section{INTRODUCTION}

Cogeneration also called combined heat and power (CHP) is the simultaneous production of electrical or mechanical energy (power) and useful thermal energy from a single energy stream such as oil, coal, natural or liquefied gas, biomass or solar [1]. The conventional sources of energy are getting consumed at a very fast rate, which has focused attention to the clean and renewable sources of energy [2]. Cogeneration is widely recognized worldwide as an attractive alternative to the conventional power and heat generating options due to its low capital investment, short gestation period, reduced fuel consumption and associated environmental pollution, and increased fuel diversity [3]. Cogeneration is not a new concept. Industrial plants led to the concept of cogeneration back in the 1880s when steam was the primary source of energy in industry, and electricity was just surfacing as a product for both power and lighting [4]. The use of cogeneration became common practice as engineers replaced steam driven belt and pulley mechanisms with electric power and motors, moving from mechanical powered systems to electrically powered systems. During the early parts of the 20th century, most electricity generation

Manuscript received October 13, 2014; revised April 23, 2015. This work was supported in part by the Republic of Turkey Marmara University Scientific Research Commission in Istanbul FEN-A-120514-0156.

The authors are with the Faculty of Technology, Department of Mechanical Engineering, Marmara University, Kadikoy, Istanbul 34722 Turkey (e-mail: matmaca@marmara.edu.tr, enderyilmaz@marmara.edu.tr, berk.kurtulus@marmara.edu.tr). was from coal fired boilers and steam turbine generators, with the exhaust steam used for industrial heating applications. In the early 1900 s, as much as $58 \%$ of the total power produced in the USA by on-site industrial power plants was estimated to be cogenerated [5]. Because of energy price increases and uncertainty of fuel supplies, systems that are efficient and can utilize alternative fuels started drawing attention. In addition, cogeneration gained attention because of the lower fuel consumption and emissions associated with the application of cogeneration [6]. Today, because of these reasons, various governments especially in Europe, US, Canada and Japan are taking leading roles in establishing and/or promoting the increased use of cogeneration applications not only in the industrial sector but also in other sectors including the residential sector [5].

In the literature, many studies can be seen about cogeneration systems. Allen and Kovacik [7] studied advantages of cogeneration systems with a gas turbine and heat recovery system that uses the exhaust of a gas turbine. Sahin et al. [8] and Sahin and Kodal [9] performed performance analyses of cogeneration foundations with respect to maximum exergy criterion using finite time thermodynamics. Yilmaz [10] has carried out a performance analysis based on alternative performance criteria for a reversible Carnot cycle, modified for cogeneration, with external irreversibilities. Criterions used in examining cogeneration systems have been evaluated by Feng et al. [11]; a new thermodynamic performance criterion named cogeneration efficiency has been propounded. According to new criterion, not only should the energy utilization factor be considered but also the rate of cost of heat and electric should be determined. Benelmir and Feidt [12] studied cogeneration systems and strategies of energy management. They compared conventional energy systems with cogeneration systems in terms of cost of investment, economic advantage, and time of repayment. Bilgen [13] performed exergetics and thermoeconomic analyses for a cogeneration unit with a gas turbine. He examined cogeneration systems with gas turbines and combined cogeneration systems depending on the ratio of heat/power and the determined time of repayment based on efficiencies of the first and second law of thermodynamics and costs. Khaliq and Kaushik [14] examined the second-law approach for the thermodynamic analysis of the reheat combined Brayton/Rankine power cycle. They found that the exergy destruction in the combustion chamber represents over $50 \%$ of the total exergy destruction in the overall cycle. The combined cycle efficiency and its power output were maximized at an intermediate pressure-ratio, and increased sharply up to two reheat-stages and more slowly thereafter. Marrero et al. [15] analyzed a combined triple (Brayton/ Rankine/ Rankine) (gas/ steam/ ammonia) power cycle. One goal of their study was to find what configuration would 
achieve a thermal efficiency of $60 \%$ when reasonably practical constraints for system parameters are used. Lund et al. [16] and Lund and Andersen [17] studied implementation strategy and optimization of cogeneration plants. Recently, optimization studies on exergetic performance of gas turbine based cogeneration systems can be seen in the references [18], [19].

The aim of this paper is to maintain a study by using real consumptions of housing complex in Turkey. A cogeneration system is considered for the study. Electricity and natural gas consumption quantities have been obtained from housing complex for this study. Cost analysis study was conducted. According to cost analysis study, it is found that cogeneration system is economical and depreciation time is very quickly. Finally as it is resulted from payback period approach the system is paid off itself in 1.33 year, approximately 16 months.

\section{DEVELOPMENT OF COGENERATION IN TURKEY}

For the last years cogeneration has played a significant part in the Turkish energy strategy, with plans to satisfy a considerable portion of Turkey's requirements for electricity from cogeneration [20]. Turkey, with its young population and growing energy demand per person, its fast growing urbanization, and its economic development, has been one of the fast growing power markets of the world for the last years It is expected that the demand for electric energy in Turkey will be 556 billion $\mathrm{kWh}$ by the year 2020 [21].

In 1998, of Turkey's final energy consumption 38\% was used by the industrial sector, followed by residential at $34 \%$, transportation at $19 \%$, the agricultural sector at $5 \%$, and the nonenergy use at $3 \%$. The share of the industrial sector in this consumption is expected to continue to grow at approximately $9 \%$ per year and to $59 \%$ in 2020 . As Turkey's economy has expanded in recent years, the consumption of oil has increased. This growth in consumption is expected to continue up to the year 2020 at a rate of about $4.5 \%$ per year. The proportion of oil is expected to decrease somewhat as natural gas usage increases. In this regard, oil accounted for $46 \%$ of this consumption, with coal at $20 \%$ and natural gas at $8 \%$ in 1998 . It is projected that these figures will be $29 \%$ for oil, $35 \%$ for coal, and $11 \%$ for natural gas by 2020 [22], [23].

Notable efforts are assigned to ensure the use of domestic resources insofar as is possible in order to meet the demand of energy, but as is already known, the meeting of energy demand of the country totally by local resources is out of question [24]. Because of its limited energy resources, Turkey is heavily dependent on imported oil and gas. There are major oil and gas pipelines going through Turkey and additional pipelines are being constructed or are being planned. Turkey has approximately 8 billion tons of coal reserves, of which a large portion is of low quality [20]. This means that there is some production of lignite, which is used as a fuel for thermal power plants, domestic consumers, and industry. Turkey does not have satisfactory reserves of natural gas. As of the end of 1998, the known total reserves were 15.5 billion $\mathrm{m}^{3}$, of which 12.4 billion $\mathrm{m}^{3}$ is recoverable. The production of natural gas in Turkey began in 1976 and was realized as 253 and 565 million $\mathrm{m}^{3}$ in 1997 and 1998, respectively. However, this production is estimated to be 150 million $\mathrm{m}^{3}$ in 2010 and 121 million $\mathrm{m}^{3}$ in 2020 [22]. Turkey's potential indigenous sources available for power generation are comprised of 105 billion $\mathrm{kWh}$ lignite, 16 billion $\mathrm{kWh}$ hard coal, and 125 billion $\mathrm{kWh}$ hydroelectric resources. The total potential adds up to 246 billion kWh [24]. The Fig. 1 shows the installed cogeneration capacity development in Turkey [21].

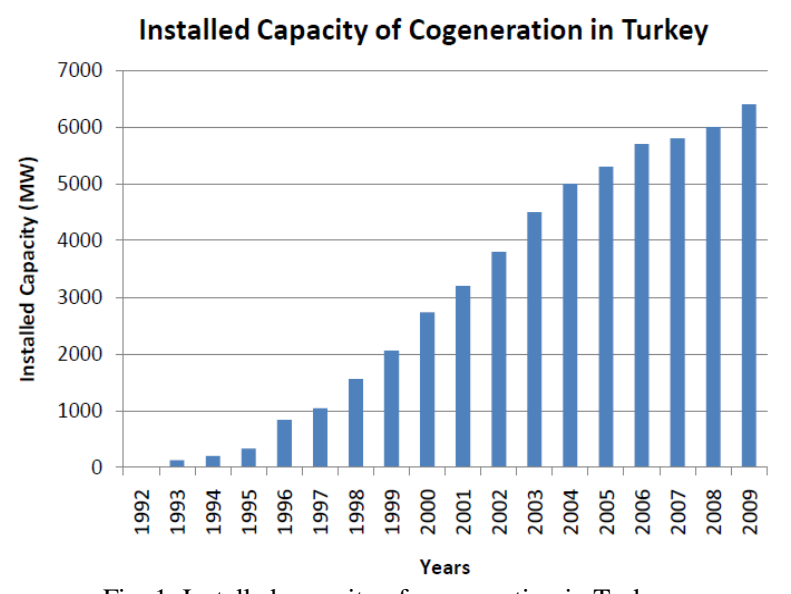

Fig. 1. Installed capacity of cogeneration in Turkey.

\section{ApplicAtion of COGENERAtion ON A Housing COMPLEX}

In this study application of cogeneration on housing complex was made in Istanbul. It is shown in Fig. 2, a housing complex in Istanbul.

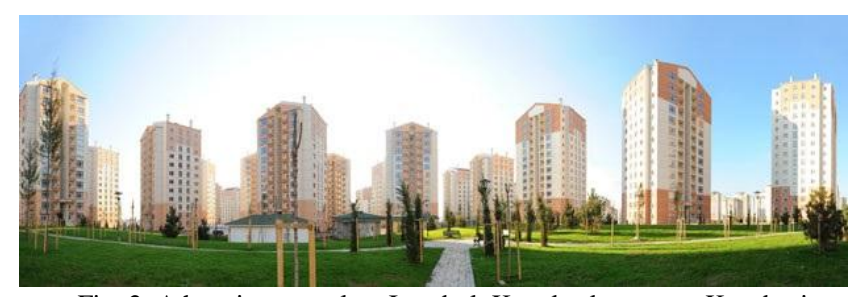

Fig. 2. A housing complex, Istanbul, Kucukcekmece - Kayabasi.

Site: Housing complex with 1340 flats

Operating hours: $8060 \mathrm{~h}$

Total hours in a year $=24 \times 365=8760 \mathrm{~h}$

$$
\begin{gathered}
\text { Capacity Factor }(C F)=\frac{\text { operating Hours }}{\text { Total Annual Hours }} \\
C F=\frac{O H}{T A H}=0.92 \\
C F=0.92
\end{gathered}
$$

The plant life $(n)$ is 20 years and it is consumed natural gas as fuel in there. There is no steam requirement at the system. Hot water between $70-90^{\circ} \mathrm{C}$ is needed at the central heating installation. Main purpose is to supply electricity demand of housing complex and partially supplying heating demand.

In calculations, electricity produced more than requirement is sold with $20 \%$ discount rate [25], [26]. Natural gas used for cooking at houses is not included to calculations. The full stop is used as thousand separators while comma is used as decimal point. Electricity and natural gas demand of housing complex can be seen in the Table I and Table II [26]. 
TABLE I: ELECTRICITY DEMAND OF HOUSING COMPLEX

\begin{tabular}{cccc}
\hline \hline & & $\begin{array}{c}\text { Number } \\
\text { of } \\
\text { Months }\end{array}$ & $\begin{array}{c}\text { Total } \\
{[\mathrm{kWh}]}\end{array}$ \\
\hline January & 167 & 1340 & 223780 \\
February & 149 & 1340 & 199660 \\
March & 171 & 1340 & 229140 \\
April & 115 & 1340 & 154100 \\
May & 128 & 1340 & 171520 \\
June & 139 & 1340 & 186260 \\
July & 141 & 1340 & 188940 \\
August & 138 & 1340 & 184920 \\
September & 157 & 1340 & 210380 \\
October & 134 & 1340 & 179560 \\
November & 163 & 1340 & 218420 \\
December & 158 & 1340 & 211720 \\
& & $E_{e}$ & $\mathbf{2 3 5 8 4 0 0}$ \\
\hline \hline
\end{tabular}

TABLE II: NATURAL GAS DEMAND OF HOUSING COMPLEX

\begin{tabular}{ccccc}
\hline \hline Months & $\begin{array}{c}\text { Cons. } \\
{\left[\mathrm{m}^{3}\right]}\end{array}$ & $\begin{array}{c}\text { Cons. } \\
{[\mathrm{kWh}]}\end{array}$ & $\begin{array}{c}\text { Number } \\
\text { of } \\
\text { Houses }\end{array}$ & $\begin{array}{c}\text { Total } \\
{[\mathrm{kWh}]}\end{array}$ \\
\hline January & 137 & 1288 & 1340 & 1726569.9 \\
February & 146 & 1373 & 1340 & 1839994.2 \\
March & 120 & 1129 & 1340 & 1512324.0 \\
April & 90 & 846 & 1340 & 1134243.0 \\
May & 23 & 216 & 1340 & 289862.1 \\
June & 17 & 160 & 1340 & 214245.9 \\
July & 19 & 179 & 1340 & 239451.3 \\
August & 17 & 160 & 1340 & 214245.9 \\
September & 22 & 207 & 1340 & 277259.4 \\
October & 84 & 790 & 1340 & 1058626.8 \\
November & 119 & 1119 & 1340 & 1499721.3 \\
December & 132 & 1241 & 1340 & 1663556.4 \\
& & & $E_{t}$ & 10535857.2 \\
\hline \hline
\end{tabular}

In Table I and Table II, $E_{e}$ and $E_{t}$ represent total annual electricity demand and total annual natural gas demand respectively. These consumption distributions can be seen explicitly at Fig. 3 and Fig. 4 monthly.

\section{Electricity Consumption}

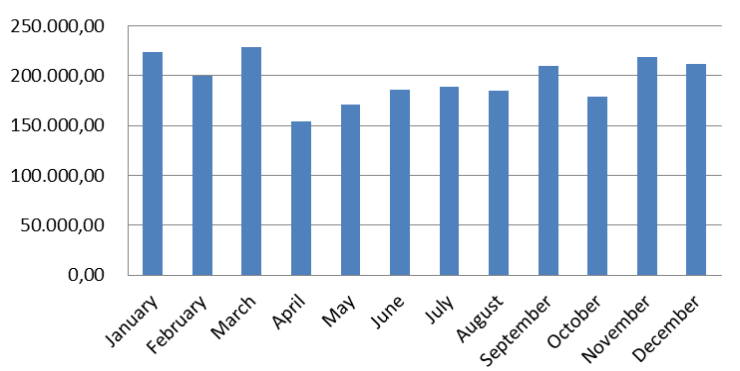

Fig. 3. Monthly electricity consumption (kWh).

\section{Natural Gas Consumption}

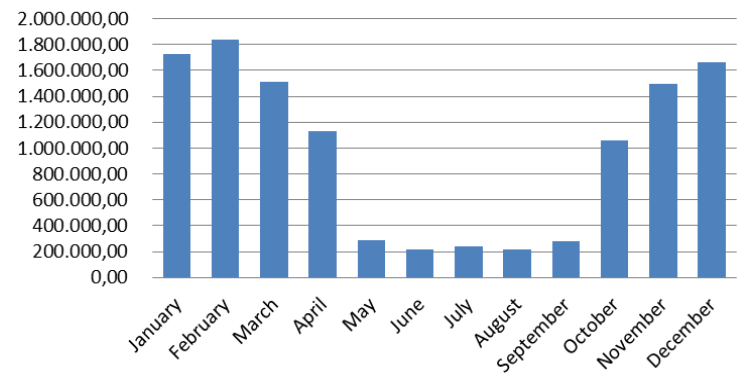

Fig. 4. Monthly natural gas consumption (kWh).
One of the ways to select capacity is according to peak consumption value. As it seen from the electricity consumption figure, the most electricity consumption in the year was occurred in March. Electricity demand in this month is $229140 \mathrm{kWh}$. According to assumption of facility operates 24 hours and 30 days.

Power Requirement;

$$
\begin{aligned}
& P=\frac{\text { Electricity Consumption March }}{\text { Working Hour in a Month }} \\
& P=\frac{229140}{24 \times 30}=318.25 \mathrm{kWh}
\end{aligned}
$$

When the systems losses and inner electricity consumptions are taken in to consideration, it is suitable to choose system power more than calculated power requirement. GE's Jenbacher type 2 gas engine is suitable to supply electrical demand of the site as shown in Fig. 5. The cost of system is 290000\$. Systems' efficiencies, outputs and $\mathrm{NO}_{x}$ emissions are at the Table III and Table IV. The technical properties of gas engine is as shown at the Table $\mathrm{V}$.

TABLE III: OUTPUTS AND ELECTRICALLY EFFICIENCIES OF GAS ENGINE

\begin{tabular}{cccc}
\hline \hline Natural Gas & \multicolumn{3}{c}{$1500 \mathrm{rpm} / 50 \mathrm{~Hz}$} \\
\hline $\mathrm{NO}_{X}$ & Type & $P_{e l}(\mathrm{~kW})$ & $\eta_{e l}(\%)$ \\
$500 \mathrm{mg} / \mathrm{m}^{3} \mathrm{~N}$ & 208 & 330 & 38.7 \\
\hline
\end{tabular}

TABLE IV: OUTPUTS AND THERMAL EFFICIENCIES OF GAS ENGINE

\begin{tabular}{cccc}
\hline \hline Natural Gas & \multicolumn{3}{c}{$1500 \mathrm{rpm} / 50 \mathrm{~Hz}$} \\
\hline $\mathrm{NO}_{X}$ & Type & $P_{t h}(\mathrm{~kW})$ & $\eta_{\text {th }}(\%)$ \\
$500 \mathrm{mg} / \mathrm{m}^{3} \mathrm{~N}$ & 208 & 363 & 42.6 \\
\hline
\end{tabular}

TABLE V: TECHNICAL DATAS OF GAS ENGINE

\begin{tabular}{ll}
\hline Configuration & In line \\
Bore (mm) & 135 \\
Stroke (mm) & 145 \\
Displacement/cylinder (L) & 2.08 \\
Speed (rpm) & $1.500(50 \mathrm{~Hz}), 1.800(60 \mathrm{~Hz})$ \\
Mean piston speed (inch/s) & $7,3(1.500 \mathrm{rpm}), 8,7(1.800 \mathrm{rpm})$ \\
& Generator set, cogeneration \\
Scope of supply & system, generator set/ \\
& cogeneration in container \\
& Natural gas, flare gas, propane, \\
Applicable gas types & biogas, sewage gas, landfill gas, \\
& coal mine gas, special gases (e.g. \\
Engine type & coke, wood, and pyrolysis gases) \\
Number of cylinders & J208 GS \\
Total displacement (L) & 8 \\
\end{tabular}

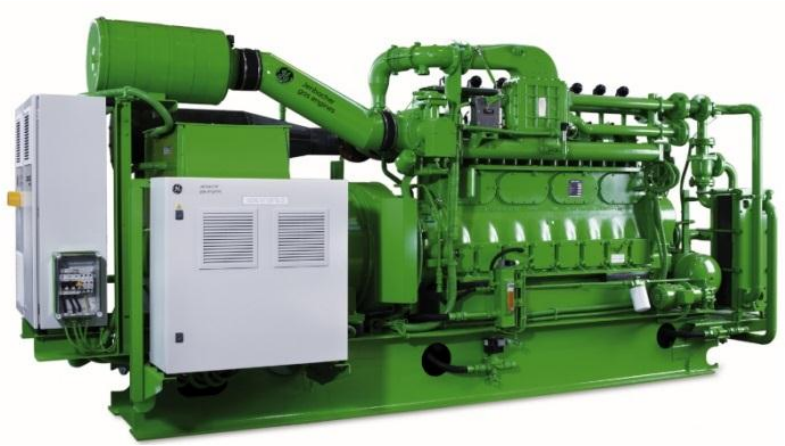

Fig. 5. GE Jenbacher type $2330 \mathrm{~kW}$ gas engine.

Natural gas is used at the system, and values of natural gas 
are given below:

$$
\begin{aligned}
& \text { Lower Heating Value of Natural Gas }\left(H_{u}\right) \\
& \qquad=33.858 \mathrm{~kJ} / \mathrm{m}^{3}=9.405 \mathrm{kWh} / \mathrm{m}^{3}
\end{aligned}
$$

Price of Natural Gas $(f)=0.48451 \$ / \mathrm{m}^{3}$

$$
=0.05152 \$ / \mathrm{kWh}
$$

Specific Fuel Consumption $(S F C)=\frac{A D N}{H_{u} \times \eta_{e l}}$

Annual Day Number $(A D N)=3600$

$$
S F C=\frac{3600}{33858 \times 0.387}=0.2798 \mathrm{~m}^{3} / \mathrm{kWh}
$$

Fuel Consumption per Hour $(F C H)=S F C \times P_{e l}$

$$
F C H=0.2798 \times 330=92.334 \mathrm{~m}^{3} / \mathrm{h}
$$

Annual Fuel Consumption $(A F C)=F C H \times O H$

$$
A F C=92334 \times 8060=744212.04 \mathrm{~m}^{3} / \text { year }
$$$$
\text { Annual Heat Generation }(A H G)=O H \times P_{t h}
$$

$$
A H G=O H \times 363=2925780 \mathrm{kWh}
$$

where $P_{t h}$ is thermal power capacity of the plant:

$$
2925780<10535857.20 \mathrm{kWh}\left[E_{t}\right]
$$

Heat generated from cogeneration does not supply the total heat demand. Additional heat demand will be supplied by using natural gas individually.

Revenues of the system consist of only the electricity sales. The amount of electricity and heat are determined with the specifications of chosen gas engine. More electricity which is not needed is sold to another consumer.

\section{A. Savings in Electricity}

Turkey's demand for energy and electricity is increasing rapidly. Energy consumption has increased at an annual average rate of $4.3 \%$ since 1990 [27]. As would be expected, the rapid expansion of energy production and consumption has brought with it a wide range of environmental issues at the local, regional and global levels. Turkey's carbon dioxide $\left(\mathrm{CO}_{2}\right)$ emissions have grown along with its energy consumption.

BEDAS is responsible for electricity distribution in European side of Istanbul.

The amount of electricity is not purchased from:

$$
B E D A S=2358400 \mathrm{kWh} / \text { year }
$$

Average Electricity Price $(A E P)=0.16691 \$ / \mathrm{kWh}$

$$
\begin{gathered}
\text { Annual Electricity Generation }(A E G)=O H \times 330 \\
=2659800 \mathrm{kWh}
\end{gathered}
$$

$$
\begin{aligned}
& \text { Saving in Electricity }(S E)=N P E \times A E P \\
& S E=2358400 \times 0.16691=393640.54 \$
\end{aligned}
$$

$$
\text { Electricity Sold }(E S)=A E G-N P E
$$

$$
E S=2659800-2358400=301400 \mathrm{kWh} / \text { year }
$$

Electricty Sale Price $\left(f_{e}\right)=0.13353 \$ / \mathrm{kWh}$

(approximately $20 \%$ discount is accepted for private user)

$$
\text { Income from Electricity Sold }(I E S)=f_{e} \times E S
$$

$$
I E S=0.13353 \times 301400=40245.942 \$ / \text { year }
$$

Total Savings from Electricity $(T S E)=S E+I E S$

$T S E=393640.54+40245.942=433886.482 \$ /$ year

\section{B. Final Stage}

Without cogeneration:

$$
\begin{gathered}
\text { Total Thermal Energy Demand }\left(E_{t}\right) \\
=11670100.2 \mathrm{kWh}
\end{gathered}
$$

Natural Gas Expenditure Without Generation $(N G E)=$

$$
E_{t} \times f
$$

$N G E=11670100.22 \times 0.05152=601243.56 \$$ year

With cogeneration:

$$
\text { Fuel Flow Rate }(F F R)=\frac{P_{e l}}{H_{u} \times \eta_{e l}}
$$

$$
F F R=\frac{330}{33858 \times 0.387}=0.0252 \mathrm{~m}^{3} / \mathrm{s}
$$

Fuel Consumption of Gas Engine (FCGE)

$$
=F F R \times A D N \times O H
$$

$$
\text { Annual Day Number }=3600
$$

$$
\begin{aligned}
& F C G E=0.0252 \times 3600 \times 8060=731203.2 \mathrm{~m}^{3} / \text { year } \\
& F C G E=731203.2 \times 9.405=6876966.096 \mathrm{kWh} / \text { year }
\end{aligned}
$$

Natural Gas Savings for Cogeneration $(N G S C)=\frac{H G C}{\eta_{b}}(14)$

$$
\text { Heat Generated from Cogeneration }(H G C)
$$$$
=2925489.6 \mathrm{kWh}
$$

where $\eta_{b}$ is efficiency of boiler and

$$
\eta_{b}=0.95
$$

$$
N G S C=\frac{2925489.6}{0.95}=3079462.737 \mathrm{kWh} / \text { year }
$$

This calculation indicates if we obtained that energy by using boiler that is efficiency 0,95 , what fuel consumption would be. In other words, this value, also, reveals natural gas savings from thermal energy by using cogeneration.

Total Natural Gas Demand with Cogeneration $(T N D G C)=$

$$
E_{t}+F C G E-N G S C
$$




$$
\begin{aligned}
& \text { TNDGC = 11670100.2+6876966.096-3079462.737 } \\
& =15462823.51 \mathrm{kWh} \\
& \begin{aligned}
\text { Total Natural Gas Expenditure with Cogeneration } \\
(\text { TNGEC })=T N G D C \times f
\end{aligned} \\
& \text { TNGEC }=15467603.559 \times 0.05152 \\
& =796890.94 \$ \text { year }
\end{aligned}
$$

Natural gas consumption will be rised with cogeneration system when compared to case without cogeneration, because of the natural gas consumption of gas engine to produce electricity.

\section{Economic Feasibility}

In this study, economic feasibility of the system is assessed according to two different methods. One of these is payback period, another is lifetime levelized cost method. Payback period is the one of the simplest method to assess economic feasibility of the system. Payback period gives information about how much time required system pays itself off.

Payback period are calculated as follow:

Net Annual Income

$$
\begin{aligned}
& =\text { Total Saving from Electricity } \\
& \text { + Heat Revenue - Fuel Cost } \\
& \text { - Operating and Maintenance Cost } \\
& N A I=T S E+H R-F C-O M C \\
& \text { Heat Revenue }(H R)=H S G C \times f \\
& H R=3079462.74 \times 0.05152=158653.92 \$ \\
& F C=F C G E \times f \\
& \text { Fuel Cost }(F C)=6876966.096 \times 0.05152 \\
& =354301.29 \$ \\
& \text { Operating and Maintenance Cost } \\
& =\text { Annual Electricity Generation } \\
& \times \text { Unit Operating and Maintenance Cost } \\
& O M C=A E G \times U O M C \\
& O M C=2659536 \times 0.0074=19680.57 \$ \\
& \text { Payback Period }(P P)=\frac{T C C}{T S E+H R-F C-O M C} \\
& P=\frac{290000}{433886.482+158653.92-354301.29-19680.57}
\end{aligned}
$$

\section{Lifetime Levelized Cost of Energy of CHP Plant}

Lifetime levelized cost method is complicated than payback period method. In this method, Interest and escalation rate is taken into consideration over system life. This method is based on finding electricity cost per kWh in a year. This cost is compared with cost of electricity taken from grid to decide whether system is feasible or not.

The cost per $\mathrm{kWh}$ is calculated via the levelized cost of energy $\left(C_{e}\right)$

Levelized Cost of Electricity

$=$ Levelized Capital Cost per kWh

+ Levelized Fuel Cost per kWh

+ Operating and Maintenance Cost per kWh

$$
C_{e}=C_{c}+C_{f}+C_{O M}
$$

$$
C_{c}=\frac{i\left(\frac{Z}{E}\right)}{1-\frac{1}{(1+i)^{n}}}
$$

Total Capital Cost $(Z)=290000 \$$

$$
n=\text { Plant Life }
$$

Interest rate $(i)=5.75 \%[28]$

Annual Total Energy Demand $(E)$

$=$ Annual Electricity Energy Demand $\left(E_{e}\right)$

+ Annual Thermal Energy Demand $\left(E_{t}\right)$

$$
E=E_{e}+E_{t}
$$

$$
\begin{gathered}
E=2358400+10535857.20=12894257.20 \mathrm{kWh} \\
C_{c}=\frac{0.0575\left(\frac{290000}{12894257.20}\right)}{1-\frac{1}{(1+0.0575)^{20}}}=0.002 \\
C_{f}=\frac{F_{0}}{E} C E L F
\end{gathered}
$$

$$
F_{0}=\text { Annual Fuel Cost }
$$

$C E L F=$ Constant Escalation Levelization Factor

$$
\begin{gathered}
F_{0}=\frac{E_{E}}{\eta} \times \frac{3600}{H_{u}} \times f \\
F_{0}=\frac{12894257.20}{0.387} \times \frac{3600}{33858} \times 0.05152=182516.62 \$ \\
C R F=\frac{i(1+i)^{n}}{(1+i)^{n}-1}
\end{gathered}
$$

$C R F=$ Cost Reduction Factor

$$
\begin{gathered}
C R F=\frac{0.0575(1+0.0575)^{20}}{(1+0.0575)^{20}-1}=0.0854 \\
\text { Escalation Rate }(r)=1.12 \%[29] \\
k=\frac{1+r}{1+i} \\
k=\frac{1+0.0112}{1+0.0575}=0.9562 \\
C E L F=\frac{k\left(1-k^{n}\right)}{1-k} \times C R F \\
C E L F=\frac{0.9562\left(1-0.9562^{20}\right)}{1-0.9562} \times 0.0854=1.1036
\end{gathered}
$$




$$
\begin{gathered}
C_{f}=0.07 \$ / \mathrm{kWh} \\
C_{O M}=0.0074 \times C E L F \\
C_{O M}=0.0082 \$ / \mathrm{kWh} \\
C_{e}=0.002+0.07+0.0082=0.0802 \$ / \mathrm{kWh}
\end{gathered}
$$

where $C_{e}$, levelized cost of electricity per $\mathrm{kWh} ; C_{c}$, levelized capital cost per kWh; $C_{f}$, levelized fuel cost per $\mathrm{kWh} ; C_{o \& m}$, operating and maintenance cost per $\mathrm{kWh} ; r$, escalation rate; $E$, annual total energy demand; $E_{e}$, annual electricity energy demand; $E_{t}$, annual thermal energy demand; $i$, interest rate; $Z$, total capital cost; $F_{o}$, annual fuel cost; $C E L F$, constant-escalation levelization factor; $C R F$, cost reduction factor; $n$, plant life; $\eta$, efficiency of plant; $H_{u}$, lower heating value; $f$, Price of Natural Gas.

\section{RESUlTS AND DISCUSSION}

Turkey, with its young population and growing energy demand per person, its fast growing urbanization, and its economic development, has been one of the fast growing power markets of the world for the last two decades. It is expected that the demand for electric energy in Turkey will be by the year 2020 [30]. Turkey is heavily dependent on expensive imported energy resources that place a big burden on the economy and air pollution is becoming a great environmental concern in the country. Air pollution from energy utilization in the country is due to the combustion of coal, lignite, petroleum, natural gas, wood and agricultural and animal wastes. On the other hand, owing mainly to the rapid growth of primary energy consumption and the increasing use of domestic lignite, $\mathrm{SO}_{2}$ emissions, in particular, have increased rapidly in recent years in Turkey.

The electricity losses come from the transmission and distribution systems. The loss in the transmission line of Turkey is about $2.5-3 \%$, which is within world standards. However, the distribution loss is considerably high at $15 \%$ [30]. It is expected that the distribution losses will be reduced Cogeneration, or autoproduction, is known as Combined Heat and Power (CHP), which has been developed by governmental support to support the continuing need for additional electricity generation. The main advantage of cogeneration is that less input energy is consumed than would be required to produce the same thermal and electrical products in separate processes. Additional benefits of cogeneration often are reduced environmental emissions. There were only for cogeneration plants in operation in 1994, with a total capacity of only $30 \mathrm{MWe}$. Since then, incentives were offered by TEDAS (Turkish Electricity Distribution Company) in the form of a $100 \%$ tax deduction, duty exemptions for autoproduction facilities, and guaranteed purchasing of any surplus electricity [31].

Consequently, cogeneration systems will consume less fuel per unit, so that consumers will be protected from unstable energy prices. However, the distribution losses occurring in the transmission of electricity will be prevented. Thus, consumers will reach with a more reliable way to electricity and heat. As the amount of fuel consumed per unit of energy in cogeneration systems is less, cogeneration systems will reduce air pollution and greenhouse gas emissions.

Although this method containing the additional cost increased the investment costs in the first phase, it is clear that cogeneration systems are useful systems in terms of user and an environmental in the long run. TOKI (Turkish housing administration) should pursue innovator policies in creating a sustainable environment and it should apply in its projects. In addition, TOKI should guide other construction company.

\section{CONCLUSION}

At the end of the study, as it is clearly seen from payback period approach the system is paid off itself in 1.33 year, approximately 16 months. When the system is evaluated according to levelized life cycle cost, it can be understood the electricity production by CHP is cheaper when compared to that sold by BEDAS. Moreover the fuel expenditure of system consists of notable parts of cost of electricity. If the result is checked according the administrive approach, it is clearly seen that system is very profitable. Although the investment cost is high, supplying energy demand, possibility of selling surplus electricity production and using energy resources efficiently enhance application chance of this cogeneration system. This cogeneration system, also, will reduce transmission line losses at grid that are formed when electrical energy is carried to consumer.

Based on Turkish Renewable Energy Law, for maximum $500 \mathrm{~kW}$ installed capacity combined heat and power system, there is no need legal obligation and establish a company. Non-legal and legal person can be installed the system and they can sell surplus energy.

\section{NOMENCLATURE}

$\begin{array}{ll}A D N & \text { Annual day number } \\ A E G & \text { Annual electricity generation } \\ A E P & \text { Average electricity price } \\ A F C & \text { Annual fuel consumption } \\ A H G & \text { Annual heat generation } \\ C_{e} & \text { Levelized cost of electricity } \\ C_{c} & \text { Levelized capital cost } \\ C_{f} & \text { Levelized fuel cost } \\ C_{O M} & \text { Levelized operating and maintenance cost } \\ C E L F & \text { Constant escalation levelization factor } \\ C F & \text { Capacity factor } \\ C R F & \text { Cost reduction factor } \\ E & \text { Annual total energy demand } \\ E_{e} & \text { Annual electricity energy demand } \\ E_{t} & \text { Annual thermal energy demand } \\ E S & \text { Electricity sold } \\ f & \text { Price of natural gas } \\ f_{e} & \text { Electricity sale price } \\ F_{0} & \text { Annual fuel cost } \\ F C & \text { Fuel cost } \\ F C G E & \text { Fuel consumption of gas engine } \\ F C H & \text { Fuel consumption per hour } \\ F F R & \text { Fuel flow rate } \\ H_{U} & \text { Lower heating value of natural gas } \\ H G C & \text { Heat generated from cogeneration } \\ H R & \text { Heat revenue } \\ i & \text { Interest rate } \\ I E S & \text { Income from electricity sold } \\ n & \text { Plant life } \\ N A I & \text { Net annual income } \\ N G E & \text { Natural gas expenditure without generation } \\ N G S C & \text { Natural gas savings for cogeneration } \\ O H & \text { Operating hours } \\ O M C \text { Operating and maintenance cost } \\ P_{t h} \quad \text { Thermal power capacity } \\ & \\ F C & \end{array}$


$P_{e l} \quad$ Electricity power capacity

$P P \quad$ Payback period

$S E \quad$ Saving in electricity

SFC Specific fuel consumption

$T A H \quad$ Total annual hours

TCC Total capital cost

TNDGC Total natural gas demand with cogeneration

TNGEC Total natural gas expenditure with cogeneration

TSE Total savings from electricty

UOMC Unit operating and maintenance cost

Z Cost of system

\section{REFERENCES}

[1] ASHRAE, ASHRAE Handbook HVAC Systems and Equipment, USA, 2000.

[2] M. Atmaca, "Efficiency analysis of combined cogeneration systems with steam and gas turbines," Energy Sources, Part A: Recovery, Utilization, and Environmental Effects, vol. 33, pp. 360-363, 2010.

[3] P. Purohita and A. Michaelowab, "CDM potential of bagasse cogeneration in India," Energy Policy, vol. 35, pp. 4779-4798, 2007.

[4] J. A. Orlando, Cogeneration Design Guide, USA, 1996.

[5] C. A. Frangopoulos, The European Educational Tools on Cogeneration, European Commission, 2001.

[6] H. I. Onovwiona and V. I. Ugursal, "Residential cogeneration systems: Review of the current technology," Renewable and Sustainable Energy Reviews, vol. 10, pp. 389-431, 2006.

[7] R. P. Allen and J. M. Kovacik, "Gas turbine cogeneration principles and practices," Journal Engineering Gas Turbines and Power, vol. 106, pp. 725-730, 1984.

[8] B. Sahin, A. Kodal, I. Ekmekci, and T. Yilmaz, "Exergy optimization for an endoreversible cogeneration cycle," Energy, vol. 22, pp. 551557, 1997.

[9] C. Wu, L. Chen, and J. Chen, Recent Advances in Finite-Time in Thermodynamics, New York: Nova Science Publishers, USA, 1999.

[10] C. Wu, L. Chen, and J. Chen, Thermodynamics, New York: Nova Science Publishers, USA, 2004

[11] T. Yilmaz, "Optimization of cogeneration systems under alternative performance criteria," Energy Conversion Management, vol. 45, pp. 939-945, 2004.

[12] X. Feng, Y. N. Cai, and L. L. Qian, "A new performance criterion for cogeneration systems," Energy Conversion Management, vol. 39, pp. 1607-1609, 2004.

[13] R. Benelmir and M. Feidt, "Energy cogeneration systems and energy management strategy," Energy Conversion Management, vol. 39, pp. $1791-1802,1998$.

[14] E. Bilgen, "Exergetic and engineering analysis of gas turbine based cogeneration systems," Energy, vol. 25, pp. 1215-1229, 2000.

[15] A. Khaliq and S. C. Kaushik, "Second-law based thermodynamic analysis of Brayton/Rankine combined power cycle with reheat," Applied Energy, vol. 78, pp. 179-197, 2004.

[16] I. O. Marrero, A. M. Lefsaker, A. Razani, and K. J. Kim, "Second law analysis and optimization of a combined triple power cycle," Energy Conversion Management, vol. 43, pp. 557-573, 2001.

[17] H. Lund, G. Siupsinskas, and V. Martinaitis, "Implementation strategy for small CHP-plants in a competitive market: The case of Lithuania," Applied Energy, vol. 3, pp. 214-227, 2005.

[18] H. Lund and A. N. Andersen, "Optimal designs of small CHP plants in a market with fluctuating electricity prices," Energy Conversion Management, vol. 46, pp. 893-904, 2005.

[19] Y. Ust, B. Sahin, and T. Yilmaz, "Optimization of a regenerative gas-turbine cogeneration system based on a new exergetic performance criterion: Exergetic performance coefficient (EPC)," Proceedings of the Institution of Mechanical Engineers, vol. 221, pp. 447-456, 2007.

[20] T. Yilmaz, "Performance optimization of a gas turbine-based cogeneration system," Journal of Physics D: Applied Physics, vol. 39, pp. 2454-2458, 2006.

[21] A. Hepbasli, "Development of cogeneration in Turkey," Energy Sources, vol. 24, pp. 195-204, 2002.
[22] H. Aras, "Condition and development of the cogeneration facilities based on auto production investment model in Turkey," Renewable and Sustainable Energy Reviews, vol. 7, pp. 553-559, 2003.

[23] World Energy Council Turkish, "World energy council Turkish national committee, energy statistics 1998 (in Turkish)," presented at the Turkish Eighth Energy Congress, 1999.

[24] M. Mendilcioglu, "Restructuring the Turkish electricity market (in Turkish)," presented at the Turkish Eighth Energy Congress, Ankara Turkey, 2000.

[25] H. A. Danisman, "Energy outlook of Turkey," presented at the Conference on Prospects for Cleaner Fossil Fuels Systems in Sustainable Development, Ankara, Turkey, 1999.

[26] Energy Market Regulatory Authority. [Online]. Available: www.epdk.gov.tr

[27] S. Bilgen, S. Keles, A. Kaygusuz, A. Sarı, and K. Kaygusuz, "Global warming and renewable energy sources for sustainable development: A case study in Turkey," Renewable and Sustainable Energy Reviews, vol. 12, pp. 372-96, 2008.

[28] Central Bank of the Republic of Turkey. [Online]. Available: www.tcmb.gov.tr

[29] Turkish Electricity Distribution Company. [Online]. Available: www.tedas.gov.tr

[30] E. Toklu, M. S. Guney, M. Isik, O. Comakli, and K. Kaygusuz, "Energy Production, Consumption, Policies and Recent Developments in Turkey," Renewable and Sustainable Energy Reviews, vol. 14, pp. $1172-1186,2010$

[31] F. C. Kilic and D. Kaya, "Energy production, consumption, policies, and recent developments in Turkey," Renewable and Sustainable Energy Reviews, vol. 11, pp. 1312-1320, 2007.

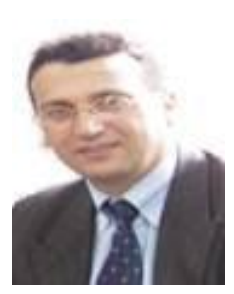

Mustafa Atmaca was graduated in 1993 from Yildiz Technical University, Faculty of Mechanical Engineering. In 1994, he was with Marmara University, Faculty of Technical Education as a research assistant in the Department of Mechanical, his academic life was started from here. Then he received the master's degree in 1996 and completed doctorate study in 2003. In 2010 he was a faculty member as well as an associate professor in Marmara University, Faculty of Technology, Department of Mechanical Engineering. $\mathrm{He}$ is a member of Chamber of Mechanical Engineers. His main research areas include wind tunnel testing and optimization, exergy, HVAC systems, energy efficiency in building.

Ender Yilmaz was born in Istanbul in 1983. He works now in Istanbul Technical University. He is a research assistant in Marmara University. His main research areas are energy efficiency in buildings, exergy, energy economy. He is a member of Chamber of Mechanical Engineers.

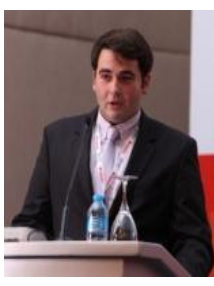

Ahmet Berk Kurtulus was born in Istanbul in 1988. In 2010, he was graduated from the Faculty of Engineering, Department of Mechanical Engineering, Sakarya University. Then he continued his study in 2011 at the Department of Mechanical Engineering of Thermal-Fluid Program, Istanbul Technical University Institute of Science. In the same year, he was also worked at the Faculty of Technology Department of Mechanical Engineering Marmara University, as a research assistant. Currently, his graduate education and research assistantship are continues. His main research areas include two-phase flows, transfer mechanisms in porous media, exergy, HVAC systems, energy efficiency in buildings, cryogenic systems and applications. He is a Chamber of Mechanical Engineers member as well as a member in Turkish Heat Science and Technique Association. 